\title{
Original Support of an after Piercing Lobular Keloid Scar: About a Case
}

\author{
Christiane Koudoukpo $^{1}$, Hugues Adégbidi ${ }^{2 *}$, Spéro Raoul Hounkpatin ${ }^{1}$, Félix Atadokpèdé ${ }^{2}$, \\ Julienne Téclessou ${ }^{2}$, Fabrice Akpadjan², Bérénice Dégboé-Sounhin ${ }^{2}$, Hubert G. Yédomon ${ }^{2}$ \\ ${ }^{1}$ Faculté de Médecine de Parakou, Université de Parakou, Parakou, Bénin; ${ }^{2}$ Faculté des Sciences de la Santé de Cotonou, Université \\ d’Abomey-Calavi, Cotonou, Bénin. \\ Email: *adegbidih@yahoo.fr
}

Received September $10^{\text {th }}, 2013$; revised October $8^{\text {th }}, 2013$; accepted October $16^{\text {th }}, 2013$

Copyright (c) 2013 Christiane Koudoukpo et al. This is an open access article distributed under the Creative Commons Attribution License, which permits unrestricted use, distribution, and reproduction in any medium, provided the original work is properly cited.

\begin{abstract}
Keloids are tissue repair formed by exuberant fibrosis appearing after a skin wound, burn, vaccination or post inflammatory (folliculitis or acne lesion). This condition causes standard aesthetic prejudice to those who are affected. Its management is difficult and its evolution meshes recurrences. We report here a case of giant keloid in the right ear lobe after a piercing and its support.
\end{abstract}

Keywords: Piercing Lobular Keloid Scar

\section{Introduction}

Keloids are tissue repair formed by exuberant fibrosis appearing after a skin wound, burn, vaccination or post inflammatory (folliculitis or acne lesion). We report a case of giant keloid in a right ear lobe piercing and its support.

\section{Observation}

A 28 years old dark-skinned woman consulted in June 2011 for an asymptomatic tumoral lesion of the right ear lobe evolving since November 1999. The injury occurred after a piercing. In his history, we noted two attempts of complete surgical excision of the keloid lesion without further treatment associated, but with recurrence after each removal. Clinical examination revealed an oval normochromic tumoral lesion, pedicle based with normal surface appearance measuring $6 \mathrm{~cm} \times 4.5 \mathrm{~cm}$ large, sitting at the base of the right ear lobe. This is attached at the extreme left to a rounded bead keloid about $1 \mathrm{~cm}$ diameter with normal surface and sharp boundaries (Figure 1). Surgical resection was then performed under local anesthesia after infiltration of lidocaïne (Xylocaine ${ }^{\circledR}$ $2 \%)$. The procedure consisted in an incision made in the keloid area the edge of healthy skin, excision with was

*Corresponding author. intra keloid, but very close to the healthy zone, keeping a thin rim of keloidal tissue. The suture was performed with absorbable suture $(4-0)$, point by point in a plane substantially keloid area, then left in open air, without dressing. Touching Povidone-iodine (Betadine ${ }^{\circledR}$ dermal) two times a day, followed by application of betamethasone dipropionate (Diprosone ${ }^{\circledR}$ cream) once a day under occlusion at least 12 hours per day from the fifth day of action were recommended. The occlusion dressing was continued for 6 weeks. There is no complaint or recurrence 24 months after the cessation of any treatment (Figure 2).

\section{Discussion}

The clinical diagnosis of keloid is the appearance of hard tumor mass after trauma, infection or spontaneously [1]. Keloïd used to grow, have no tendency for spontaneous regression. This condition differs from hypertrophic scar which is limited to the site of the original skin wound, occurring before a three months period and has a tendency to spontaneous regression [2]. One of the great problems of the treatment of keloids is that they tend to recur if we proceed with surgical resection, and sometimes more important. When the surgery is done, it is usually associated with other treatments (pressure therapy, corticosteroids, radiation). The first therapeutic choice of 


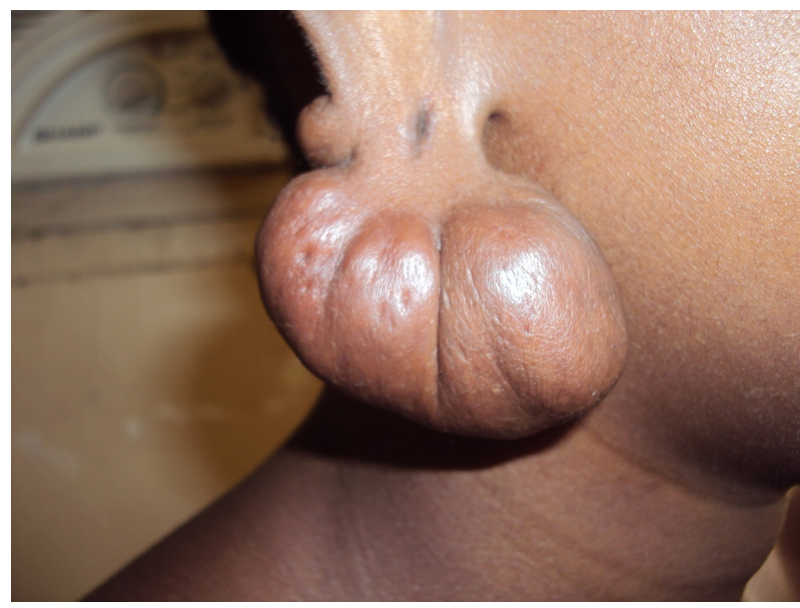

Figure 1. Showing the giant lobular keloid.

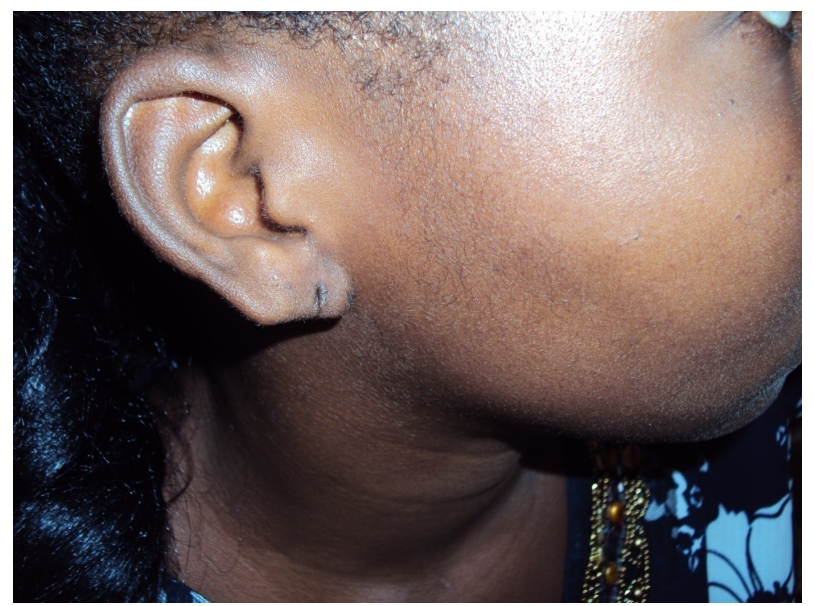

Figure 2. After surgeon and topical steroids under occlusion treatment.

doctors is often intra-lesional injections of corticosteroids. This improves the appearance of the lesion, but often not enough to make it disappears. The best results are obtained on the keloid neck and ear lobes, the worst on the chest. It can persist a residual coloration of the skin after treatment [3]. The therapeutic approach used in our clinical case is not described in the literature for this localization. Intra lesional infiltration after partial or total excision is described in the literature, giving variable results depending on the localizations of lesions. In lobular keloids, the result is better but poor on other areas [3]. This poor outcome in non-lobular keloids may be due to irritation at the injection site promoting recurrence. The absorption of topical corticosteroid is increased by occlusion and gave the favorable evolution of our patient: this therapeutic approach could be proposed in the therapeutic support of lobular keloids. It has the advantage of avoiding the pain associated with post excision intralesional infiltration.

\section{Conclusion}

The treatment of keloids is necessary to the existence of disabling functional signs, mechanical discomfort and unsightly damage. The interest of this case involves surgical excision with topical steroids under occlusion to spare patients the pain of post resection and intra-lesional injections. This therapeutic approach deserves to be known.

\section{REFERENCES}

[1] S. O. Niang, A. A. Sankale, F. Fall, et al., "The Role of Surgery in the Treatment of Keloids in Dakar,” Médecine d'Afrique, Vol. 56, No. 4, 2009, pp. 224-226.

[2] T. A. Mustoe, R. D. Cooter, M. H. Gold, et al., "Recommendations on the Clinical Support of Scars," Journal des Plaies et Cicatrisations, Vol. 34, 2002, pp. 7-16.

[3] I. Bodokh, “Therapeutic Support of Keloids,” EMC Cosmétologie et Dermatologie Esthétique, 50-460-A10, 2003, 6 . 